\title{
MONITORING OF THE SURFACE OZONE CONCENTRATIONS IN THE WESTERN BANAT REGION (SERBIA)
}

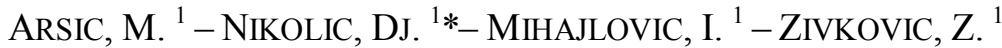 \\ ${ }^{1}$ University of Belgrade, Technical Faculty in Bor \\ Vojske Jugoslavije 12, 19210 Bor, Serbia \\ (phone: +38130424 555; fax: +38130421078) \\ *Corresponding author \\ e-mail:djnikolic@tf.bor.ac.rs
}

(Received 24 ${ }^{\text {th }}$ Sept 2011; accepted 22 ${ }^{\text {nd }}$ June 2014)

\begin{abstract}
This paper presents the results of measuring the concentrations of ozone, VOCs (benzene, toluene, $m$ - and $p$-xylene, $o$-xylene and ethylbenzene), nitrogen oxides (NO, $\mathrm{NO}_{2}$ and $\mathrm{NOx}$ ), $\mathrm{CO}, \mathrm{H}_{2} \mathrm{~S}$, $\mathrm{SO}_{2}$ and $\mathrm{PM}_{10}$ in the ambient air in parallel with recording the meteorological parameters: temperature, solar radiation, relative humidity, barometric pressure, wind speed and direction during the year 2009. The measurements were performed at the measuring station located within an agricultural area near the city of Zrenjanin (Serbian Banat, Serbia). The results are presented in this paper as average values in winter and summer vs. time of day, and as average daily values vs. measurement date. Several correlations of the ozone concentration $v s$. atmospheric observables were made, together with Principal Component Analysis. The statistical analysis of the obtained data, based on Principal Component Analysis (PCA), led to result that $80.87 \%$ of the variance in the measured values could be described with five factors. A high level of intercorrelation of VOCs, NOx and $\mathrm{CO}$ was determined. These pollutants were all grouped in factor 1 , which described $42.85 \%$ of variances of the measured values. According to the VOCs/NOx and VOCs/CO ratios (which were 0.26 and 0.029 , respectively), it was determined that production of tropospheric ozone is a VOCs sensitive process for the investigated region.
\end{abstract}

Keywords: pollutants, ozone, VOCs, nitrogen oxides

\section{Introduction}

The occurrence of high levels of tropospheric ozone $\left(\mathrm{O}_{3}\right)$ is currently a matter of worldwide concern due to its harmful influence on human health, crops and ecosystems derived from its highly oxidative nature (WHO, 2000; EEA, 2003). Reports published by the European Environmental Agency (EEA) are indicating a global tendency of increasing ozone concentrations in urban regions, especially in the EU and USA (EPA, 2007). These reports also highlight the negative influence of increased ozone concentration on human health (EPA, 2009). The tendency of increasing ozone concentrations is also being reported in other parts of the world (Abdul-Wahab and AlAlawi, 2002), gaining more and more attention from scientists and other investigators. Episodes of ozone concentration enhancement in the ambient air of rural zones are regularly being reported. This is increasing the risk of slower development of the agricultural production in these seemingly unpolluted areas (Gonzales et al., 2010), as well as in partially industrialized regions (Castell et al., 2010). An increased concentration of tropospheric ozone in ambient air is not only an environmental problem of a country; but it also presents a source of health problems of its population as well as increased costs to the economy. At the same time, enhancement of the tropospheric ozone concentration represents a global problem that demands local actions (Parnel, 2006). 
Ozone, however, is unique among pollutants because it is not emitted directly into the air. It is secondary pollutant that results from complex chemical reactions in the atmosphere. It is a well-known phenomenon that the ozone results from the complex chemical interaction of nitrogen oxides $(\mathrm{NOx})$, carbon monoxide $(\mathrm{CO})$ and volatile organic compounds (VOCs) in the presence of UV radiation (Jacob, 2000; Trainder et al., 2000; Lengual et al., 2004; Duan et al., 2008). Variation in ozone concentration is also related to some meteorological variables (temperature, surface wind direction, speed, and global radiation) (Klaus et al, 2001).

The mechanism of tropospheric ozone production is not yet fully understood. It is usually assumed that the $\mathrm{NO}_{2} / \mathrm{NO}$ ratio and ozone concentration are correlated. In this manner, if the correlation is positive, it is considered that the process of ozone production is "NOx sensitive". In such a case, the VOCs/NOx ratio is large, leading to a tendency for NOx to produce ozone (Shao, et al., 2009). On the contrary, if the VOCs/NOx ratio is small, then NOx has a tendency to inhibit ozone production (Duan, et al., 2008). In such cases, the overall ozone production depends on the VOCs content, and the ozone concentration is regarded as being "VOCs sensitive (Lengyel et al., 2004; Shao et al., 2009). Some researchers reported the influence of $\mathrm{SO}_{2}$ and $\mathrm{PM}_{2.5}$ on the ozone concentration (Odman Talat et al., 2009), while others considered meteorological parameters (Abdul-Wahab and Al-Alawi, 2002; Languel et al, 2004) and other influences as important factors (Madronich and Flocke, 1999).

To enable efficient prediction of tropospheric ozone as functions of other pollutants, their concentrations and meteorological conditions, which influence the production of ozone in the ambient air, attempts at mathematical modeling, based on statistical methods, have been widely reported. These methods are applied to data obtained from real time - real conditions measurements of the ozone concentration in the ambient air. For statistical analysis of this type of data, the Multiple Linear Regression Analysis (MLRA) method could be used (Otto, 1999; Langyel et al., 2004; Živković et al., 2009a, 2009b; Mihajlovic et al, 2010; Djordjević et al., 2010). Other potential tools for mathematical modeling are: Principal Component Analysis/Absolute Principal Component Score (PCA/APCS) (Duan et al., 2008) and PCA modeling (Multiple Regression Analysis -MLR, Partial Least Squares - PLS as well as Principal Component Regression - PCR) (Lengyel et al., 2004, Djuric et al., 2010). For complex dependencies, the methods of nonlinear regression analysis are widely used, among which Artificial Neural Networks (ANNs) are frequently applied (Spellman, 1999; Elkamel et al., 2001; Abdul-Wahab and Al-Alawi, 2002; Sousa et al., 2007, Živković et al., 2010).

Measurements of the ozone concentration in the ambient air commenced in Serbia a few years ago. However, a comprehensive study concerning its genesis, level of concentration and possible risks that it presents to human health have not hitherto been performed, because information on ozone dependences in this region of Europe is limited. The aim of this study was to obtain an insight on ground-level ozone concentrations in the central region of the Serbian Banat, a major agro-industrial region in Serbia with an important production of crops, potentially sensitive to this pollutant (such as grape, vegetables, cereal and fruits) and where a large number of protected species are present. Therefore, the daily and seasonal variability of ozone were measured at a measuring site within the study area during the plant growing season and a number of factors that might influence its levels. A model of the chemical mechanism was applied to assess the sensitivity of ozone formation on NOx and VOCs in the 
region. Simultaneously, the repercussion that ozone concentration might have on air quality and its potential serious effects on human health as well as on vegetation were explored.

\section{Materials and methods}

\section{Area of study}

The locality where the measurements were facilitated, the Banat, is a region in southeastern Europe divided among three countries: the eastern part belongs to Romania, the western part to Serbia (the Serbian Banat, mostly located in Vojvodina, except for a small part that is in Central Serbia) and a small northern part in Hungary. It is the part of the Pannonian plain bordered by the Danube to the south, the Theiss to the west, the Mures to the north and the southern Carpathians to the east. The Serbian part of the Banat, Figure 1, is an area of 8,997 square kilometers located in the northeast of Serbia. Zrenjanin is the center of this region, occupying 1,326 square kilometers, with a population of 80,000 . From the whole territory that belongs to this municipality, $82.5 \%$ is covered by large-scale farmlands. This area is the part of a humid continental climate region; with the average annual temperature of $11.2^{\circ} \mathrm{C}$ and $622 \mathrm{~mm}$ of rainfall per year. Wind directions are mostly from the east, southeast or northwest. The average number of sunny hours in this area is 2,000 to 2,200 per year.

The Banat is one of the most fertile regions of Europe. The main agricultural products of this region are all kinds of cereals. This region is also convenient for the growth of sugar beet and tobacco. Vegetables grown in this region include: pepper, tomato, cabbage, spinach, etc. Grape vines are grown in the southern part of the region. Large scale industrial facilities include: the agro industry, milling, the brewing industry, sugar production, the textile industry, and brick production. Moreover, oil and natural gas are exploited in the region. Most of the agricultural plants that are grown in Banat are vulnerable to ozone air pollution (Fumagalli, 2001). For this reason, the present research study considers the ozone air quality problem of this region.

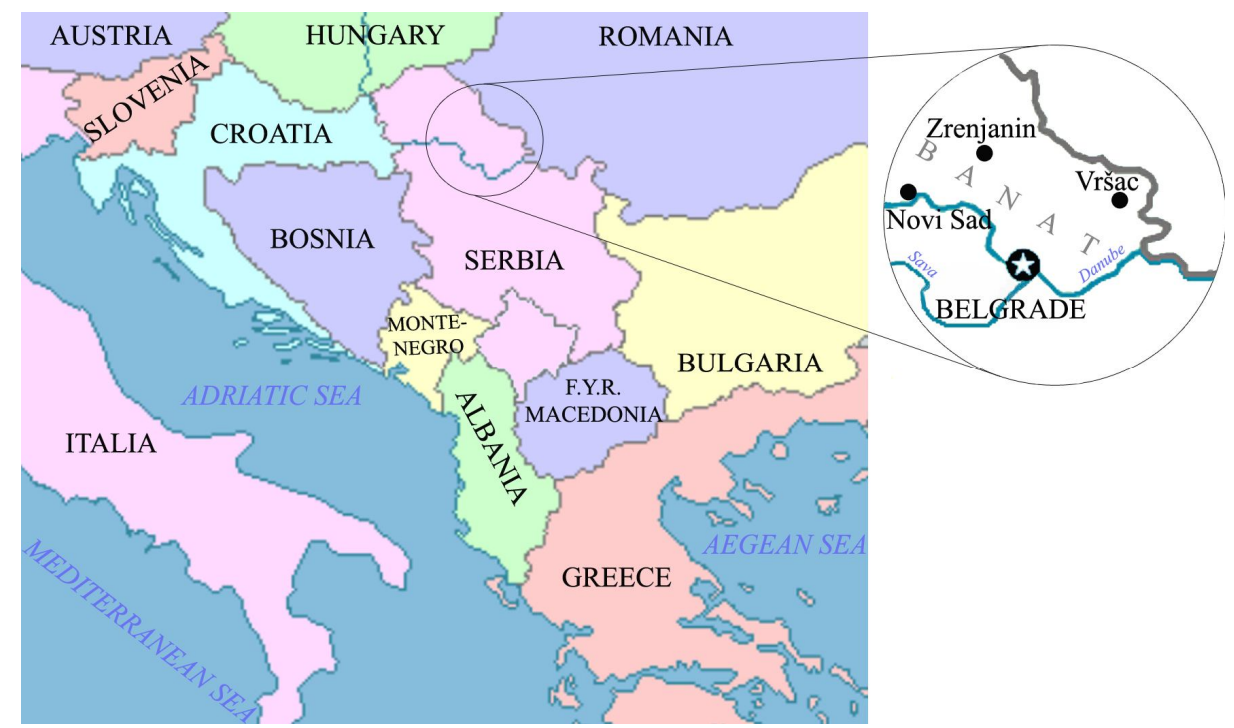

Figure 1. The investigated Serbian Banat region and its position in Europe 


\section{Air quality Monitoring and Meteorological data}

Continuous measurement of the air pollutants was facilitated in an automatic measuring station, located in the city of Zrenjanin. This station measures air pollution levels originating from exhaust gasses and other sources of pollution. The following air pollutants are continually measured at this location: BTEX (benzene, toluene, ethylbenzene and xylene) according to the EN 14662 method; ozone according to the EN 14625, ISO 13964 method; carbon monoxide according to the EN 14626, ISO 4224:2000 method; $\mathrm{PM}_{10}$ (Particulate matter) according to the EN 12341 method; $\mathrm{NO} / \mathrm{NO}_{2} / \mathrm{NOx}$ (nitrogen oxides) according to the EN 14211 method and $\mathrm{H}_{2} \mathrm{~S} / \mathrm{SO}_{2}$ (sulfur compounds) according to the EN 14212, ISO 10498:2004 method. Measurements are repeated in 2-minute intervals and the hourly average value for each hour in $0-24$ intervals are calculated. The results of the measurements are publicly available on-line. The measurements, calibration of the equipment, quality control and standardization are organized by the Regional Environmental Protection and Sustainable Development Committee, located in Novi Sad, the administrative capital of the Vojvodina region. The meteorological parameters: wind speed and wind direction, air temperature and humidity, atmospheric pressure, rainfall per year and solar radiation intensity are measured at the same measuring station as the air pollutants concentration, with the same dynamics.

The potential risk of ozone air pollution is obvious in this region, considering that the measured hourly ozone concentrations are in the range $80-130 \mu \mathrm{g} / \mathrm{m}^{3}$, during the summer season. The limiting value prescribed by the EU are $80 \mu \mathrm{g} / \mathrm{m}^{3}$ (Directive 2002/3/EC) using the 1-h values measured between 08.00 and 20.00 hours Central European Time (CET) each day. Furthermore, these directives prescribe a value of $18,000 \mu \mathrm{g} / \mathrm{m}^{3} \mathrm{~h}$, for the protection of the vegetation and this limiting value became mandatory at the beginning of 2010, according to the AOT40 index.

\section{Data analysis method}

For the analysis of the ozone concentration in the ambient air in the rural vicinity of the city of Zrenjanin (Serbia), the data obtained from the automated measuring station were used. The data were collected during the year 2009, in the time periods in which all the pollutants and all meteorological parameters were measured simultaneously.

These time periods were:

Winter: 1-8 and $23-28$ February; $21-31$ December

Spring: 5 - 15 May

Summer: $13-18$ July and $1-20$ September

Autumn: $1-22$ October

During these 83 days, the measurements were conducted from 0.00 to 24.00 hours, and the hourly average values were calculated. In this way, a representative data base for credible statistical analysis was generated. A total of 1477 data sets remained after deleting error points. A Mann-Whitney U non-parametric test was used to compare between the $\mathrm{NO}_{2} / \mathrm{NO}$ ratios registered at the Zrenjanin station during episodes of high concentrations of ozone and those recorded normally. A rotated principal component analysis (PCA) was also performed with the correlation matrix of the pollutant concentrations, in order to identify potential factors determining the concentration of the studied pollutants. Statistical analysis was performed using SPSS 18.0 (SPSS Inc, Chicago, USA). 


\section{Results}

\section{Meteorology}

Temperature range recorded during above defined measuring period in 2009 was $12.5{ }^{\circ} \mathrm{C}$ to $35.1{ }^{\circ} \mathrm{C}$, average statistical value was $15.1{ }^{\circ} \mathrm{C}$. The registered wind speed ranged from negligible values, corresponding to periods of calm (minimum value 0.18 $\mathrm{m} / \mathrm{s}$ ) to a maximum value $5.57 \mathrm{~m} / \mathrm{s}$, the mean value for the measuring period was 1.68 $\mathrm{m} / \mathrm{s}$. The prevailing wind directions during the investigated period were: SE, $58 \%$; NW, $31 \%$ and $\mathrm{N}, 11 \%$, in the SE-NW orientation of the Banat region. The atmospheric pressure ranged from $270 \mathrm{hPa}$ to $1020 \mathrm{hPa}$, with an average value of $993 \mathrm{hPa}$. The intensity of the solar radiation varied during the year of the measurements; it ranged from $4 \mathrm{~W} / \mathrm{m}^{2}$ to $848 \mathrm{~W} / \mathrm{m}^{2}$, with a statistical average value of $136 \mathrm{~W} / \mathrm{m}^{2}$. The air humidity ranged from $17 \%$ to $92 \%$, with an average value of $65 \%$. The total rainfall in the year was $622 \mathrm{~mm}$, which was equally distributed throughout the year. Changes in the variances were within satisfactory borders for the entire statistical assembly, as was the value of standard deviation. This indicates that all variables behaved according to normal (Gaussian) distributions.

\section{Ambient air concentrations of O3, NOx, VOCs, CO, SO2, H2S and PM10}

Numerous investigations indicated that the ozone concentration in the ambient air is dependent on the concentrations of $\mathrm{NO}, \mathrm{NO}_{2}$ and $\mathrm{NOx}$, as well as on the concentration of volatile organic compounds (VOCs) (Duan et al., 2008; Shao et al.,2009; Gonzales et al., 2010). The automatic measurements of the ozone concentrations during the year 2009 at the Zrenjanin measuring station revealed that its concentration ranged from 1.3 $\mu \mathrm{g} / \mathrm{m}^{3}$ to $162 \mu \mathrm{g} / \mathrm{m}^{3}$ with years average of $70.1 \mu \mathrm{g} / \mathrm{m}^{3} \pm 34 \mu \mathrm{g} / \mathrm{m}^{3}$ (with a statistical reliability of $2 \sigma$ ). The average value of ozone concentration during the winter season (December - March), was $25 \pm 15 \mu \mathrm{g} / \mathrm{m}^{3}$. During the period May - October, which is relevant for vegetation growth, the average ozone concentration was $100 \pm 25 \mu \mathrm{g} / \mathrm{m}^{3}$. The average daily values of the ozone during the year 2009 are presented in Figure 2.

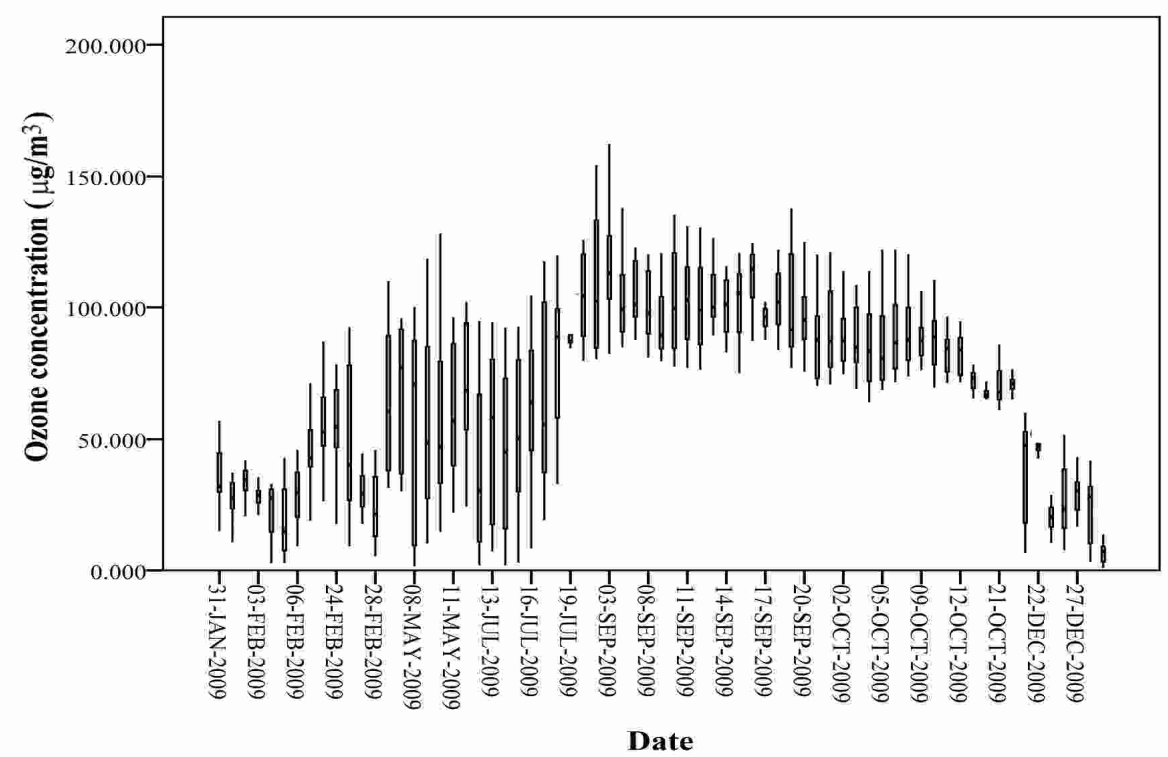

Figure 2. Variation of ozone concentration in the air during the year 2009 (average daily values) 
The daily changes in the ozone concentration exhibited the following pattern: from 7:00 the concentration started to increase, reaching a maximum value from 12:00 to 16:00 and then it decreased until 20:00, after which it remained constant until the following morning. This trend was the same throughout the year, as can be seen in Figure 3. The results presented in this figure indicate that two periods could be defined: the warm weather period (May to October) and the cold weather period (December to March), depending on the time of measurements during the day. It should be emphasized that episodes of increased ozone concentrations were recorded during the year 2009: 713 measured values above $80 \mu \mathrm{g} / \mathrm{m}^{3}(48.27 \%), 72$ values above $120 \mu \mathrm{g} / \mathrm{m}^{3}$ $(8.87 \%)$ and 9 values above $140 \mu \mathrm{g} / \mathrm{m}^{3}(0.6 \%)$.

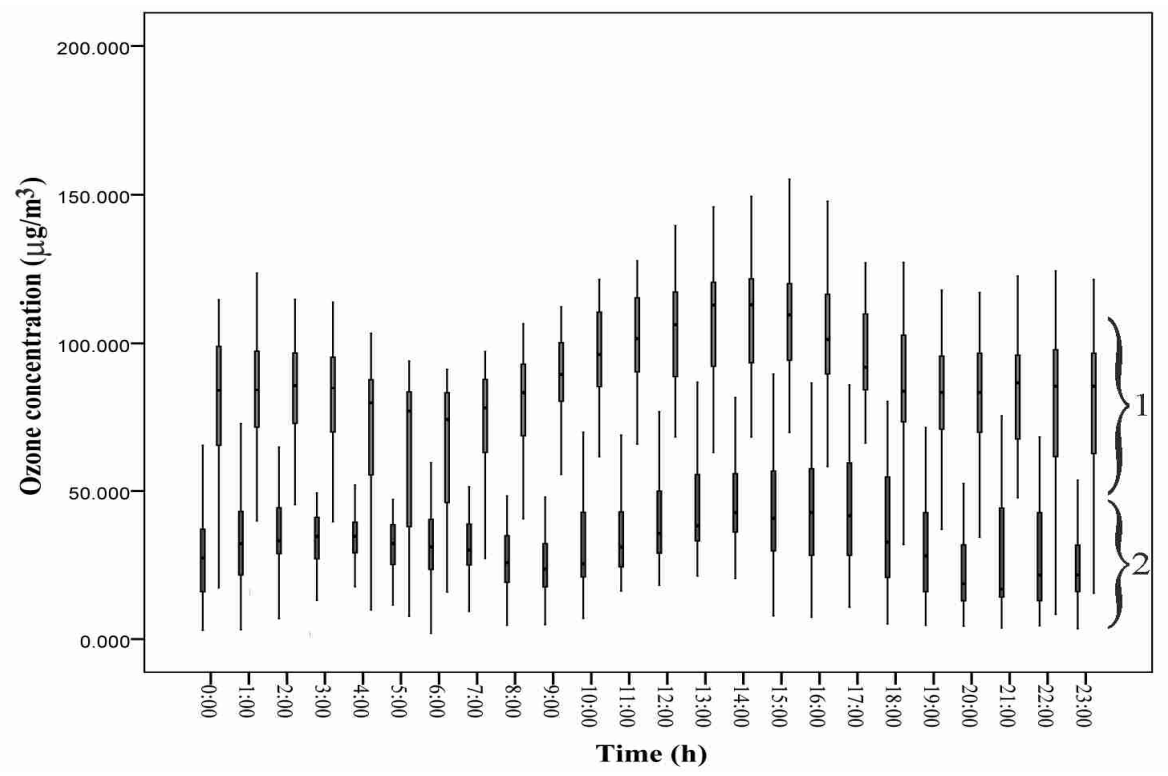

Figure 3. Variations in the daily ozone concentrations during the warm (May to October $=1$ ) and cold (December to March = 2) time periods

The obtained results have the same trend as in the case of the Ebro Basin (Spain), with 25 to $30 \%$ higher values measured in Zrenjanin during the spring and the summer seasons, which is important for vegetation growth. These values are in accordance with those measured in Virginia (USA) (Davis et al., 2010) and in towns located in the Pearl River Delta (China) (Shao et al., 2009). The average values of $\mathrm{NO}, \mathrm{NO}_{2}$ and $\mathrm{NOx}$, for the referred time period were: $28.5 \mu \mathrm{g} / \mathrm{m}^{3}, 32.9 \mu \mathrm{g} / \mathrm{m}^{3}$ and $76.5 \mu \mathrm{g} / \mathrm{m}^{3}$, respectively. These concentrations are three times higher in case of NO, and five times higher in case of $\mathrm{NO}_{2}$, compared to the values measured in a rural area of the Ebro Basin, Spain (Gonzales et al., 2010). The measured values are much higher than the prescribed limiting values for the protection of vegetation $\left(30 \mu \mathrm{g} / \mathrm{m}^{3}\right)$ and human health $\left(40 \mu \mathrm{g} / \mathrm{m}^{3}\right)$ (Martin et al., 2009). The VOCs concentrations (benzene, toluene, ethylbenzene, $m-, p$ and $o$-xylene - BTEX) were in the same range as in a rural area of the Ebro Basin, Spain (Gonzales et al.2010). The average measured values of the concentrations of the pollutants: $\mathrm{CO}, \mathrm{SO}_{2}, \mathrm{H}_{2} \mathrm{~S}$ and $\mathrm{PM}_{10}$ were $738 \mu \mathrm{g} / \mathrm{m}^{3}, 17.6 \mu \mathrm{g} / \mathrm{m}^{3}, 1.9 \mu \mathrm{g} / \mathrm{m}^{3}$ and 42 $\mu \mathrm{g} / \mathrm{m}^{3}$, respectively. These values correspond to those measured in underdeveloped industrial regions with the same ozone concentrations (Abdul-Wahab and Al-Alawi, 2002; Lengyel, et al., 2004). 
The Pearson correlation coefficients between the air pollutants and the meteorological parameters measured at the Zrenjanin measuring station during the year 2009 are presented in Table 1. Statistical analysis revealed the existence of a significant positive correlation $(r=0.687 ; p<0.01)$ between the ozone concentration and the radiation, as well as between the ozone concentration and the air temperature $(r=0.473$; $p<0.01)$. A significant negative correlation $(p<-0.624 ; p<0.01)$ exists between the ozone concentration and relative humidity. The dependence of ozone concentration on the solar radiation, temperature and relative humidity $(\mathrm{RH})$, as the most important predictors influencing the variation of its content in the ambient air, are presented in Figure 4. The obtained values of the coefficient of determination $\left(R^{2}\right)$ for the dependences of the ozone concentration on solar radiation, temperature and relative humidity are $0.472 ; 0.224$ and 0.390 , respectively. These values indicate large catalytic influences of all three parameters on the tropospheric production of ozone. These results are within the same correlation range as those reported by Gonzales et al., (2010) and Martin et al., (2009).

The concentrations of $\mathrm{NO} ; \mathrm{NO}_{2}$ and $\mathrm{NOx}$ are in negative correlation with the ozone concentration $(r=-0.380$ and $p<0.01 ; r=-0179$ and $p<0.01 ; r=-0.340$ and $p<$ 0.01 , respectively). The obtained results are in accordance with the results reported by Lengyel et al., (2004). The concentrations of the VOC group of predictors are in negative correlations with the ozone concentration. The calculated values for benzene, toluene, $m$ - and $p$-xylene, $o$-xylene and ethylbenzene are $r=-0.393$ and $p<0.01 ; r=-$ 0.327 and $p<0.01 ; r=-0.285$ and $p<0.01 ; r=-0.270$ and $p<0.01 ; r=0.267$ and $p<$ 0.01 , respectively. The $\mathrm{CO}$ concentration is in negative correlation with the concentration of ozone $(r=-0.184$ and $p<0.01)$. On the other hand, its correlations with $\mathrm{NO}, \mathrm{NO}_{2}$ and NOx are highly positive $(r=0.748$ and $p<0.01 ; r=0.844$ and $p<$ $0.01 ; r=0.844$ and $p<0.01$, respectively), indicating that all these gases originate from the same source. The group of predictors containing sulfur $\left(\mathrm{SO}_{2}\right.$ and $\left.\mathrm{H}_{2} \mathrm{~S}\right)$ are in high positive correlation with each other $(r=0.552$ and $p<0.01)$. This also indicates their same source of origin. Their correlation with ozone concentration in the ambient air is positive $\left(r=0.145 ; p<0.01\right.$ for $\mathrm{SO}_{2}$ and $r=0.207 ; p<0.01$ for $\left.\mathrm{H}_{2} \mathrm{~S}\right)$. Lower values of correlation were determined for the ozone concentration with $\mathrm{PM}_{10}$ and wind direction ( $r=-0.132$ and $p<0.01 ; r=0.127$ and $p<0.01$, respectively). The only predictor that does not have a statistically significant correlation with the ozone concentration is the wind speed. From the VOC group of pollutants, benzene has the largest negative correlation with the ozone concentration $(r=-0.393$ and $p<0.01)$. Its average concentration was $1.78 \mu \mathrm{g} / \mathrm{m} 3$ during the measuring period in this study area, which is in accordance with the results recorded in New York City during 2003 (Aleksic, et al., 2005).

The correlations between benzene and the other VOC predictors (toluene, $m$ - and $p$ xylene, $o$-xylene and ethylbenzene) are also large $(r=0.830$ and $p<0.01 ; r=0.794$ and $p<0.01 ; r=0.753$ and $p<0.01 ; r=0.806$ and $p<0.01$, respectively), which reveals the same source of emission of all the VOC pollutants. Considering the climate conditions, there is a large positive correlation between air temperature and solar radiation on the one hand and its negative correlation to relative humidity on the other $(r$ $=0.595$ and $p<0.01 ; r=-0.815$ and $p<0.01$, respectively). The correlation between relative humidity and solar radiation $(r=-0.636$ and $p<0.01)$ is also large and negative. The high values of correlations between NOx and the VOC group $(r=0.7-$ 0.8 ) also indicate that they all originate from the same source of emission. 



Figure 4. Dependence of the ozone concentration on UV radiation (a); temperature (b) and relative humidity (c)

Using the Principal Component Analysis (PCA) extraction method with Varimax rotation and Kaiser's normalization yielded five main factors that explained $80.87 \%$ of total variance, (see Table 2). Factor 1 (42.85\% of the explained variance) consisted of all VOCs, CO and NOx, with positive intercorrelations. Factor $2(17.69 \%$ of the explained variance) groups the meteorological parameters: solar radiation, temperature and relative humidity $(\mathrm{RH})$, which have the largest values of correlation coefficients with ozone. Factor 3 (9.25\% of the explained variance) indicates that the compounds containing sulfur are not emitted from the same source as the VOCs and NOx. Factor 4 groups air pressure and $\mathrm{PM}_{10}(5.55 \%$ of the explained variance). Finally, factor 5 groups the wind speed and wind direction ( $5.54 \%$ of the explained variance). 
Table 1. Correlation coefficients between the pollutants and the meteorological parameters




Table 2. Factors extracted by PCA on the pollutant concentration data within the studied area, which accounted for $80.87 \%$ of the total explained variance

\begin{tabular}{|c|c|c|c|c|c|}
\hline $\begin{array}{l}\text { Rotated component matrix } \\
\text { Total of explained variance }\end{array}$ & $\begin{array}{c}\text { Factor } 1 \\
(42.85 \%)\end{array}$ & $\begin{array}{c}\text { Factor } 2 \\
(17.69 \%)\end{array}$ & $\begin{array}{l}\text { Factor } 3 \\
(9.25 \%)\end{array}$ & $\begin{array}{l}\text { Factor } 4 \\
(5.55 \%)\end{array}$ & $\begin{array}{l}\text { Factor } 5 \\
(5.54 \%)\end{array}$ \\
\hline Ethylbenzene & .961 & & & & \\
\hline$m$-, $p$-Xylene & .959 & & & & \\
\hline Toluene & .954 & & & & \\
\hline NOx & .918 & & & & \\
\hline $\mathrm{CO}$ & .906 & & & & \\
\hline $\mathrm{NO}_{2}$ & .901 & & & & \\
\hline$o$-Xylene & .871 & & & & \\
\hline Benzene & .862 & & & & \\
\hline NO & .820 & & & & \\
\hline Radiation & & .886 & & & \\
\hline $\mathbf{O}_{3}$ & & .873 & & & \\
\hline RH & & -.828 & & & \\
\hline Temperature & & .695 & & & \\
\hline $\mathrm{H}_{2} \mathrm{~S}$ & & & .928 & & \\
\hline $\mathrm{SO}_{2}$ & & & .695 & & \\
\hline $\mathbf{P M}_{10}$ & .598 & & & .647 & \\
\hline Pressure & & & & .635 & \\
\hline Wind direction & & & & & .795 \\
\hline Wind speed & & & & & -.568 \\
\hline
\end{tabular}

\section{Discussion}

The mechanism of the photochemical production of ozone, the efficiency of tropospheric ozone production relative to the NOx concentrations, and the importance of NOx relative to VOCs and CO in the observed ozone levels were researched by Trainer, et al., 2000. As published by Klaus et al., 2001, the variation of ozone concentration is related to certain meteorological variables (temperature, surface wind direction, speed, and global radiation). The conditions for ozone production are determined by the VOCs/NOx ratio. Using this fact, the ratio of VOCs/NOx could be used to evaluate whether the production of the ozone is VOC-sensitive or NOx-sensitive (Duan et al., 2008). The values of the VOCs/NOx and VOCs/CO ratios obtained in this investigation were $0.26 \pm 0.22$ and $0.029 \pm 0.02$, respectively. Considering the low values of these ratios, the production of ozone in the investigated area could be regarded as VOC-sensitive. At the same time, $\mathrm{CO}$ is placed in Factor 1 together with the VOCs and NOx, as indicated in Table 2.

To confirm the local production of oxidants, the ambient ozone concentration was plotted against the variation of the $\mathrm{NO}_{2} / \mathrm{NO}$ ratio at the measuring station, (see Figure 5). As shown in Figure 5, the ozone concentration and the ratio of $\mathrm{NO}_{2} / \mathrm{NO}$ simultaneously increased, suggesting ozone formation in the process of $\mathrm{NO}_{2}$ photolysis. The results presented in Figure 5 indicate that an ozone concentration of $50-100 \mu \mathrm{g} / \mathrm{m}^{3}$ is achieved when $\mathrm{NO}_{2} / \mathrm{NO}$ ratio was in the range from 3 to 6 . This suggests the existence of only a small influence of $\mathrm{NOx}$ on photochemical reaction of ozone 
production. In the case of a dominant influence of NOx on ozone production, this ratio would be in the range from 5 to 15 (Shao et al., 2009).

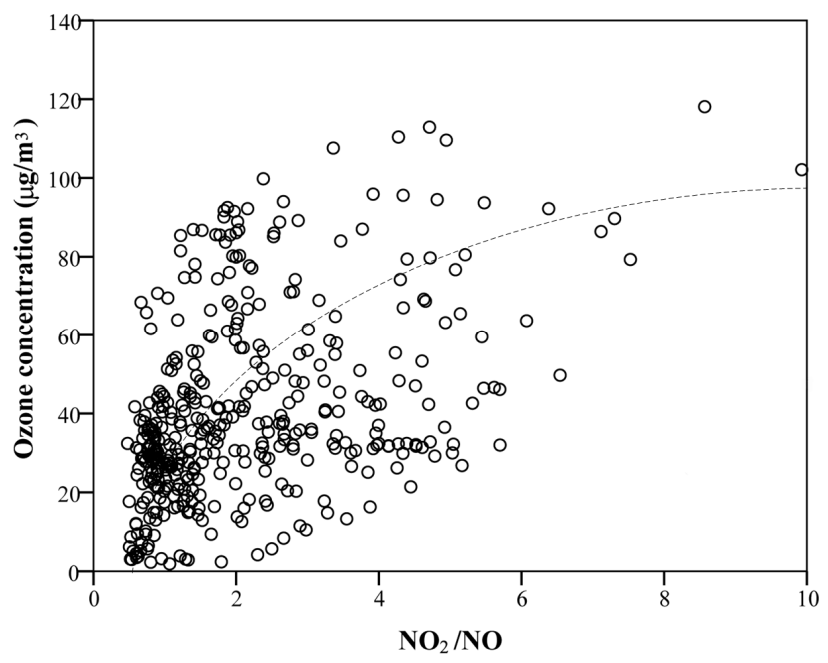

Figure 5. Relationship between the NO2/NO ratio and the O3 concentration at the Zrenjanin measuring station in 2009

The main photochemical reaction of ozone production in the troposphere can be presented as:

$$
\mathrm{NO}_{2}+\mathrm{O}_{2}=\mathrm{NO}+\mathrm{O}_{3}
$$

Thus, the ozone concentration in the troposphere could be calculated using the following equation:

$$
\left[\mathrm{O}_{3}\right]=K \cdot\left[\mathrm{NO}_{2}\right] \cdot\left[\mathrm{O}_{2}\right] /[\mathrm{NO}]
$$

where $K$ is the equilibrium constant.

Increasing the $\mathrm{NO}_{2} / \mathrm{NO}$ ratio (Figure 5) indicate the possibility of ozone production according to reaction (1). However, when the $\mathrm{NO}_{2} / \mathrm{NO}$ ratio achieves a value in the range from 3 to 6 , the ozone concentration asymptotically tends to a value of $100 \mu \mathrm{g} / \mathrm{m}^{3}$. Consequently, ozone produced by the mechanism defined by equation (1) is limited to this value.

The results obtained in this investigation also revealed that with increasing concentrations of VOCs and NOx, the ozone concentration decreased (see Figure 6). This indicates the complexity of the reactions occurring in the ambient air of the Banat region in Serbia.

Ozone production is certainly enhanced with increasing NOx level up to the point when the $\mathrm{OH}+\mathrm{NO}_{2}+\mathrm{M}$ reaction competes against the $\mathrm{OH}$ attack on the hydrocarbon concentrations. Decreasing NOx concentrations can stimulate ozone production (AEAT/ENV/R/1029 Issue 2, 2002). This was also shown by the results obtained in this investigation, where the ozone concentration increased with decreasing NOx level, indicating that the production of ozone was VOC sensitive in this region. This conclusion is based on the fact that VOCs are involved in photochemical reactions and 
interaction with NOx from anthropogenic sources of emission (Jacob, 2000; Trainer et al., 2000; Atkinson, 2000). The VOCs, besides having anthropogenic origins: automobiles, industry (Habashi, 2009) and agricultural machinery, can also originate from vegetation. Considering that PCA analysis grouped VOCs, NOx and CO in the same factor (Factor 1), with $42.85 \%$ of explained variance, it is not possible to clearly separate the sensitivity of ozone production to VOCs and NOx. It would be more accurate to consider their mixed influence, with only a little preference towards VOCs sensitivity.
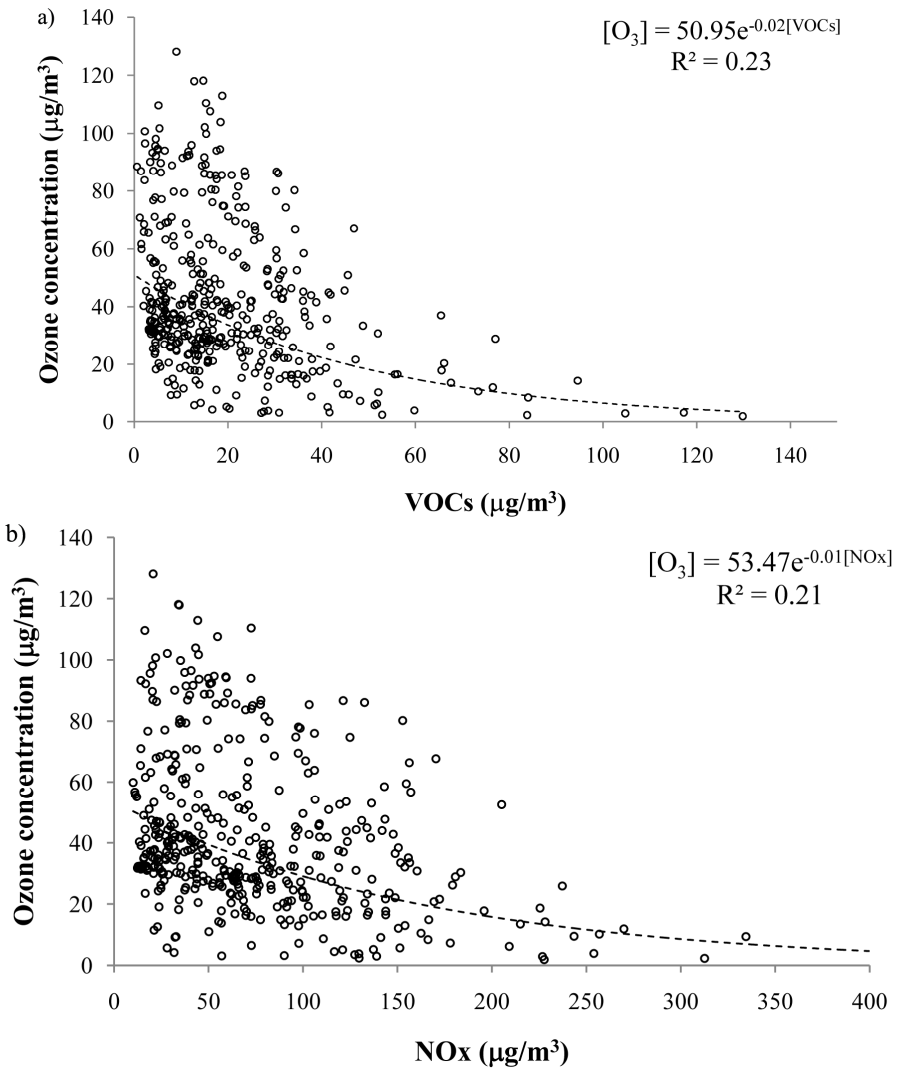

Figure 6. The non-linear dependences of the ozone concentration on the concentrations of $\operatorname{VOCs}(a)$ and NOx (b).

The episodes of high concentrations of ozone detected in this research were often associated with a noticeable increase in air temperature and significantly higher $\mathrm{NO}_{2} / \mathrm{NO}$ ratios, which indicated an increase in the presence $\mathrm{NO}_{2}$ non-attributable to traffic emissions within the area. This could be linked to an enhancement of ozone photoproduction, temperature itself being the likely surrogate of other meteorological parameters conditioning the formation of the pollutant (Gonzales et al., 2010).

Ozone concentrations in the ambient air above $18,000 \mu \mathrm{g} / \mathrm{m}^{3}$ (obtained as the average value for a five-year period of measurement) represent a potential risk of a harmful influence of ozone on vegetation, according to the AOT40 index - defined by the European directive 2008/50/EC. Considering that continuous measurements of the concentration of air pollutants at this measuring station began during the year 2008, the AOT40 index could not be determined and included in this investigation. However, 
considering the cumulative nature of the AOT40 index, it is possible to estimate its value by comparing the concentration of ozone measured in the time period from May to July, with the results of other investigators obtained under similar conditions (Gonzales et al., 2010).

For average ozone concentrations ranging from 80 to $95 \mu \mathrm{g} / \mathrm{m}^{3}$, the calculated AOT40 index was $57.147 \pm 14.114 \mu \mathrm{g} / \mathrm{m}^{3}$, as reported by Gonzales et al., (2010). For the ozone concentration measured during the investigations presented in this work (ranging from 100 to $120 \mu \mathrm{g} / \mathrm{m}^{3}$ ), the AOT40 index should by all means be much higher. These data indicate that the average value of ozone in the investigated area was about $100 \mu \mathrm{g} / \mathrm{m}^{3}$ (maximum limiting value for human health is $80 \mu \mathrm{g} / \mathrm{m}^{3}$ ) and that the estimated AOT40, would be two to three times higher that the limiting value of 18,000 $\mu \mathrm{g} / \mathrm{m}^{3}$. This indicates that the concentration of tropospheric ozone in the investigated area represents a high risk for both human health and vegetation.

The main sources of VOCs and NOx emission in the investigated region of the Serbian Banat are mostly anthropogenic. These are gases emitted from automobile exhausts, which are mostly found with the older type of diesel engines. The number of automobiles with Euro 4 engines is still small in this part of Europe. On the other hand, the frequency of the traffic is becoming larger each year. In addition, considerable sources of pollution are agro-industrial complexes and the oil refinery in Pančevo, which is about 100 kilometers away from Zrenjanin. Natural gas and oil boreholes are also located in this region as well as a central underground reservoir for storing natural gas.. All of these sources can greatly influence an increase in the ozone concentration in the ambient air. The emission of natural VOCs and BTEX originate from vegetation, which is largely present in this region considering its agricultural tradition. The levels of VOCs and NOx and the tropospheric ozone concentration represent large potential risks for human health and vegetation in the investigated region. Considering the fact that this is mostly lowland terrain, this risk could be transferred to neighboring regions as well.

\section{Conclusions}

The high measured ozone concentrations are correlated with anthropogenic activities in the Banat region during the whole year, and especially in the period of vegetation growth. The measured ozone concentrations in the ambient air were above the thresholds prescribed by the EU standards for protection of the human health and vegetation. Thus, they present a risk for the region and its surroundings.

The results presented in this paper indicate the need for continuous recording of the episodes of increased ozone concentration and for undertaking the necessary precautions to lower the NOx and VOCs emission in this region. The NOx and VOCs concentrations influence the photochemical production of ozone which, in the increased range of concentrations, represents a potential risk to human health and vegetation.

Further investigations focused on an assessment of the actual effects of ozone on these receptors need to be performed in the area. Medium to long-range transport of pollutants could play an important role with respect to ozone levels in the area, which would also require further assessment. 


\section{REFERENCES}

[1] Abdul-Wahab, S.A., Bouhamra, W., Ettoumey, H., Sowerby, B., Critenden, B.D. (1996): Development of statistical model for prediction of ozone levels in Shuaiba Industrial Area in Kuwait - Environmental Science and Pollution Research 3: 195-204.

[2] Abdul-Wahab, S.A., Bouhamra, W., Ettoumey, H., Sowerby, B., Critenden, B.D. (2000): Analysis of ozone pollution in the Shuaiba Industrial Area in Kuwait - The International Journal of Environmental Studies, Section B: Environmental Science and Technology 57: 207-224.

[3] Abdul-Wahab, S.A., Al-Alawi, S.M. (2002): Assessment and prediction of tropospheric ozone concentration levels using artificial neural networks - Environmental Modelling \& Software 17: 219-228.

[4] Aleksić, N., Boyton G., Sistila, G., Perrv, J. (2005): Concentration and trends of benzene in ambient air over New York State during 1990 -2003 - Atmospheric Environment 39: 7894-7905.

[5] Atkinson, R. (2000): Atmospheric chemistry of VOCs and NOx - Atmospheric Environment 34: 2063-2101.

[6] AEAT/ENV/R/1029/Isuse 2 (2002): Modelling of tropospheric ozone formation - Final Project Report produced for the Department for Environment, Food and Rural Affairs on Contract EPG 1/3/143.

[7] Castell, N., Mantilla, E., Salvador, R., Stein, A.F., Millan, M. (2010): Photochemical model evaluation of the surface ozone of a power plant in a heavily industrialized area of southwestern Spain - Journal of Environmental Management 91:662-676.

[8] Duan, J., Tan, J., Yang, L., Wu, S., Hao, J. (2008): Concentration, sources and ozone formation potential of volatile organic compounds (VOCs) during ozone episode in Beijing - Atmospheric Research 88: 25-35.

[9] Djordjević, P., Mihajlović, I., Živković, Ž. (2010): Comparison of linear and nonlinear statistics methods applied in industrial process modeling procedure - Serbian Journal of Management 5(2): 189-198.

[10] Djuric, I., Djordjevic, P., Mihajlovic, I., Nikolic Dj., Zivkovic Z. (2010): Prediction of $\mathrm{Al}_{2} \mathrm{O}_{3}$ leaching recovery in the Bayer process using statistical multilinear regression analysis - Journal of Mining and Metallurgy, Section B: Metallurgy 46: 161-169.

[11] EEA (2003): Europe's environment: The third assessment. Environmental Assessment Report No 10 - Copenhagen, Denmark: European Environmental Agency.

[12] EPA (2007): Ozone population exposure analysis for selected urban area - EPA$452 / \mathrm{R} / 07 / 010$

[13] EPA (2009): Provisional assessment of recent studies on health and ecological effects on ozone exposure - EPA/- 600/R//- 09/101.

[14] Fumagalli, I., Gimeno, B.S., Velissariou, D., De Temmerman, L., Mills, G. (2001): Evidence of ozone - induced adverse effects on crops in the Mediterranean region Atmospheric Environment 35: 2583-2587.

[15] Elkamel, A., Abdul-Wahab, S., Bouhamra, W., Alper, E. (2001): Measurement and prediction of ozone levels around a heavily industrialized area: a neural network approach - Advances in Environmental Research 5: 47-59.

[16] Godovich, J.M., Gilliland, A.B., Draxler, R.R., Rao, S.T. (2008). Modeling assessment of point source NOx emission reductions on ozone air quality in the eastern United States Atmospheric Environment 42: 87-100.

[17] Gonzales, L., Bermejo, R., Asuncon-Parra, M., Elustondo, D., Garrigo, J., Santamaria J.M. (2010): Rural $\mathrm{O}_{3}$ levels in the Middle Ebro Basin during plant growing season Water Air \& Soil Pollution 206: 23-34.

[18] Habashi, F. (2009): Recent trends in extractive metallurgy - Journal of Mining and Metallurgy, Section B: Metallurgy 45: 1-13. 
[19] Jacob, J.D. (2000): Heterogeneous chemistry and tropospheric ozone - Atmospheric Environment 34: 2131-2159.

[20] Klaus, D., Poth, A., Voss, M. (2001): Ozone distributions in Mexico City using principal component analysis and its relation to meteorological parameters - Atmosphere 14: 171188.

[21] Lenguel, A., Heberger, K., Paksy, L., Banhidi, O., Rajko, R. (2004): Prediction of ozone concentration in ambient air using multivariate methods - Chemosphere 57: 889-896.

[22] Martin, P., Cabanas, B., Villanueva, F., Gallero, P.M., Colmenar, I., Salgado, S. (2010): Ozone and nitrogen dioxide levels monitored in an urban area (Ciudad Real) in central southern Spain - Water, Air and Soil Pollution 208: 305-316.

[23] Madronich, S, Flocke, S. (1999): The role of solar radiation in atmospheric chemistry- In: Boule, P. (Ed), Handbook of Environmental Chemistry. Springer-Verlag, Heidelberg, Germany, pp.1-26.

[24] Mihajlović, I., Nikolić, Dj., Štrbac, N., Živković, Ž. (2010): Statistical modeling in ecological management using the artificial neural networks (ANNs) - Serbian Journal of Management 5(1): 39-50.

[25] Odman Talat, M., Hu, Y., Russell, G.A., Hanedar, A., Baylam, J.W., Brevver, P.F. (2009): Quantifying the sources of ozone, fine particulate matter, and regional haze in the Southeastern United States - Journal of Environmental Management 90(10): 3155-3168.

[26] Otto, M. (1999): Chemometrics statistics and Computer Application in Analytical Chemistry - Wiley-VCH, Weinheim, Germany

[27] Parnel, J. (2006). Reassessing the "think global act local" mandate: evaluation and synthesis - Serbian Journal of Management 1: 21-28.

[28] Shao, M., Zhang, Y., Zeng, L., Tang, X., Zhang, J., Zhong, L., Wang, B. (2009). Groundlevel ozone in the Pearl River Delta and the roles of VOC and NOx in its production Journal of Environmental Management 90: 512-518.

[29] Sousa, S.I.V., Martins, F.G., Alvim-Ferraz, M.C.M., Pereira, M.C. (2007): Multiple linear regression and artificial neural networks based on principal components to predict ozone concentrations - Environmental Modelling \& Software 22: 97-103.

[30] Spellman, G. (1999): An application of artificial neural networks to the prediction of surface ozone concentrations in the United Kingdom - Applied Geography 19: 123-126.

[31] Tranier, M., Parrish, D.D., Goldan, P.D., Roberts, J., Fehsenfeld, F.C. (2000): Review of observation-based analysis of the regional factors influencing ozone concentration Atmosphere Environmental 34: 2045-2061.

[32] Trainer, M., Parrish, D.D., Goldan, P.D., Roberts, J., Fehsenfeld. F.C. (2000): Review of observation-based analysis of the regional factors influencing ozone concentration Atmospheric Environmental 34: 2045-2061.

[33] WHO (World Health Organization) (2000): Air quality guidelines for Europe (2nd ed.) Copenhagen, Denmark: WHO Regional Publications, Regional Office for Europe.

[34] Živković, Ž., Mitevska, N., Mihajlović, I., Nikolić, Dj. (2009a): The influence of the silicate slag composition of copper losses during smelting of the sulfide concentrates Journal of Mining and Metallurgy, Section B: Metallurgy 45: 23-34.

[35] Živković, Ž., Mihajlović, I., Nikolić, Dj. (2009b): Artificial neural network applied on the nonlinear multivariate problems - Serbian Journal of Management 4: 143-154. 